\title{
EFEK MODEL PEMBELAJARAN KOOPERATIF TIPE GROUP INVESTIGATION DAN TEAMWORK SKILLS TERHADAP HASIL BELAJAR FISIKA
}

\author{
Nova Irwan dan Ridwan Abdullah Sani \\ Jurusan Fisika Pascasarjana Universitas Negeri Medan \\ J1. Willem Iskandar. Psr V - Medan \\ noirhasmy@gmail.com
}

\begin{abstract}
Abstrak. Penelitian ini bertujuan untuk: Mengetahui perbedaan hasil belajar fisika siswa melalui model pembelajaran kooperatif tipe Group Investigation dengan model pembelajaran Direct Instruction. Mengetahui perbedaan hasil belajar fisika antara kelompok siswa yang memiliki teamwork skills di bawah rata-rata dengan di atas rata-rata. Mengetahui interaksi antara model pembelajaran dengan tingkat teamwork skills siswa dalam mempengaruhi hasil belajar siswa. Penelitian ini merupakan penelitian quasi eksperimen dengan desain faktorial $2 \times 2$. Populasi penelitian ini adalah seluruh siswa kelas X. Sampel dalam penelitian ini dilakukan secara cluster random sebanyak dua kelas, dimana kelas pertama sebagai kelas eksperimen diterapkan model pembelajaran kooperatif tipe Group Investigation dan kelas kedua sebagai kelas kontrol diterapkan model pembelajaran Direct Instruction. Instrumen yang digunakan dalam penelitian ini yaitu instrumen tes hasil belajar fisika dalam bentuk uraian sebanyak 8 soal dan insrumen observasi teamwok skills yang telah dinyatakan valid dan reliabel. Data dianalisis menggunakan analisis Anava dua jalur. Dari hasil penelitian dapat disimpulkan bahwa: Hasil belajar fisika pada model kooperatif tipe group investigation lebih tinggi dibandingkan model direct interuction. Hasil belajar fisika pada kelompok siswa yang memiliki tingkat teamwork skills di atas rata-rata lebih tinggi dibandingkan di bawah rata-rata. Terdapat interaksi antara model pembelajaran dengan tingkat teamwork skills siswa dalam mempengaruhi hasil belajar siswa. Model pembelajaran kooperatif tipe group investigation sangat baik diterapkan pada kelompok siswa yang memiliki teamwork skills di atas rata-rata. Sedangkan pada model direct interuction tidak perlu memperhatikan teamwork skills.
\end{abstract}

Kata kunci: group investigation, teamwork skills, hasil belajar

\section{EFFECTS OF COOPERATIVE LEARNING MODEL TYPE GROUP INVESTIGATION AND TEAMWORK SKILLS LEARNING OUTCOMES OF PHYSICS}

\author{
Nova Irwan and Ridwan Abdullah Sani \\ Physics Education Program, Graduate State University of Medan \\ Jl. Willem Iskandar. Psr V-Medan \\ noirhasmy@gmail.com
}




\begin{abstract}
This research was aimed to: Know the difference physics student learning outcomes by cooperative learning model Group Investigation with Direct Instruction learning model. Know the difference between the physics learning outcomes of students have teamwork skills below average with above average. Know interaction between learning model with the level of students' teamwork skills in influencing student learning outcomes. This study is a quasi experiment with $2 \times 2$ factorial design. The population of this study were all students of class $\mathrm{X}$. The sample done cluster random method as much as two classes, first class as experiment class applied cooperative learning model group investigation and second class as control class applied Direct Instruction learning model. The instrument used in this study are Physics achievement test in descriptions form as much as 8 questions and Observation teamwok skills insrumen that have been declared valid and reliable. Analysis data would be using Anova two way. From the results of this study concluded that: The physics learning outcomes in the cooperative group investigation models higher than direct interuction models. The physics learning outcomes at group of students had teamwork skills above average higher than below average. There is interaction between learning model with the level of students' teamwork skills in influencing student learning outcomes. Cooperative learning model group investigation very well be applied to groups of students who have teamwork skills above average. While the direct interuction model not need to pay attention teamwork skills.
\end{abstract}

Keywords: Group Investigation, tamwork skills and Learning Outcomes

\section{PENDAHULUAN}

Berdasarkan penelitian IEA (International Association for the Evaluation of Educational Achievement) dalam TIMSS (Trends in Mathematics and Science Study) yang diselenggarakan pada tahun 2011. Hasil penelitian TIMSS 2011 menunjukkan dua hal yaitu sebagai berikut. Pertama dalam bidang sains peringkat Indonesia menurun ke peringkat 36 dari total 42 negara. Kedua, pada bidang fisika, Indonesia hanya mampu mencapai skor 397 lebih rendah dari skor rata-rata (513). Indonesia mendapat predikat low science benchmark. Predikat tersebut menyatakan bahwa siswa Indonesia hanya mampu mengenal sebagian fakta-fakta dasar dari ilmu sains khususnya dalam mata pelajaran fisika (Gonzales, 2011). Data ini menunjukkan bahwa siswa di Indonesia belum meraih hasil belajar yang baik.
Berdasarkan observasi diperoleh data yang menunjukkan hasil belajar fisika siswa di sekolah masih rendah. Hal ini dilihat dari nilai ujian tengah dan ujian akhir di bawah kriteria ketuntasan minimal. Dari Angket yang diberikan kepada 80 responden $74 \%$ siswa menjawab belum berhasil mencapai KKM sebelum melakukan remedial (ujian ulang/perbaikan). Data ini menunjukkan hasil belajar siswa di sekolah rendah. Berdasarkan hasil wawancara hasil belajar yang diukur hanya sebatas pengetahuan saja. Guru belum mengukur aspek psikomotorik dan aspek afektif. Hal ini dikuatkan oleh format penilaian yang memang hanya memuat hasil belajar dalam aspek kognitif.

Berdasarkan hasil wawancara pembelajaran fisika didominasi oleh metode ceramah dan tanya jawab. Guru lebih berorientasi pada materi pelajaran dengan alasan tuntutan kurikulum untuk mempersiapkan peserta didik 
dalam menghadapi ulangan dan ujian. Guru menginformasikan konsep-konsep yang terdapat pada buku pelajaran secara rinci, diselingi dengan tanya jawab. Berdasarkan sintak yang dilakukan guru tersebut cenderung mengikuti model pembelajaran Direct Instruction (DI). Berdasarkan angket yang diberikan kepada 80 responden. $85 \%$ siswa menginformasikan bahwa pelajaran yang dilakukan kelas dilakukan dengan metode ceramah dan tanya jawab.

Berdasarkan penjelasan diatas kiranya perlu diterapkan model pembelajaran sebagai solusi yang mendukung agar peserta didik mampu melatih dan memperoleh kemampuan untuk meraih hasil belajar tinggi. Proses belajar mengajar yang baik ditandai dengan adanya interaksi antara siswa dan guru (Dalyono, 2005). Untuk mewujudkan proses kegiatan belajar mengajar guru harus dapat merangsang dan mengarahkan siswa dalam belajar, dapat mendorong siswa dalam pencapaian hasil belajar yang optimal. Berhasil atau tidaknya proses belajar mengajar dipengaruhi oleh guru yang berperan sebagai fasilisator, motivator, atau inspirator. Guru yang dapat menjalankan suatu model pembelajaran dengan baik akan memberi pengaruh yang baik pada peserta didik termasuk mengasah keterampilan untuk meraih hasil belajar yang baik.

Salah satu model pembelajaran yang dapat digunakan untuk meningkatkan aktivitas peserta didik dan kemampuan kerjasama antara peserta didik adalah model pembelajaran kooperatif tipe group investigation (GI). Peserta didik belajar dalam kelompok-kelompok kecil yang heterogen, belajar bersama, saling membantu, dan melakukan investigasi untuk menemukan dan menyelesaikan masalah.

Pada penelitian ini, model kooperatif tipe group investigation (GI) dipilih untuk meningkatkan hasil belajara karena dapat melibatkan peserta didik secara aktif dalam proses belajar mengajar dan terlibat langsung menentukan masalah yang akan diinvestigasi. Kemampuan sosial seperti menghormati, mematuhi peraturan, penyelesaian tugas, dan toleransi menggunakan model pembelajaran kooperatif lebih baik dari pada model tradisional (Tavakoli, 2014). Perbedaan yang signifikan akan diperoleh dari model pembelajaran kooperatif tipe group investigasi dibandingkan model pembelajaran direct intruction terhadap hasil belajar siswa dimana hasil belajar lebih baik menggunakan model pembelajaran kooperatif tipe group investigation (Akcay, 2012). Model pembelajaran group investigtion tetap menawarkan peserta didik untuk berkesempatan memiliki pembelajaran mereka sendiri serta menunjukkan pengetahuan dan pemahaman mereka (Mitchell, 2008).

Untuk keberhasilan suatu pembelajaran yang menggunakan kelompok seperti model pembelajaran koopertif tipe group investigasi diperlukan kemampuan bekerja sama dalam kelompok (teamwork skills) diantara peserta didik. Kerja sama tim adalah satu set keterampilan yang digunakan individu untuk mendorong keberhasilan kelompok (Hughes, 2011). Keterampilan kerja sama tim termasuk campuran interaktif, interpersonal, pemecahan masalah dan keterampilan komunikasi yang diperlukan oleh sekelompok orang yang bekerja pada tugas bersama, dalam peran yang saling melengkapi, menuju tujuan bersama yang hasilnya lebih besar dari yang dimungkinkan oleh salah satu orang yang bekerja secara independen (Smith, 2011).

\section{MOTODE PENELITIAN}

Penelitian ini dilaksanakan di SMK pada siswa Semester I Kelas X Tahun Ajaran 2014/2015. Populasi dalam penelitian ini adalah seluruh siswa Kelas X yang terdiri dari 4 kelas. Seluruh siswa tersebut memiliki karakter yang sama. Teknik pengambilan sampel dalam penelitian ini dengan menggunakan teknik Cluster Random Sampling. Teknik ini menghendaki adanya kelompok-kelompok dalam pengambilan sampel berdasarkan atas kelompokkelompok yang ada dalam populasi. Dalam penelitian ini sampel yang diambil sebanyak 2 kelas. Kelas X-B sebagai kelas eksperimen dan kelas X-A sebagai kelas kontrol. Kelas eksperimen diberi perlakuan model pembela- 
jaran kooperatif tipe Group Investigation (KGI) dan kelas kontrol menggunakan model pembelajaran Direct Interuction (DI).

Jenis penelitian ini adalah quasi eksperiment. Desain penelitian yang digunakan adalah desain pretes dan postes. Rancangan penelitian disajikan dengan desain faktorial $2 \mathrm{x}$ 2 dengan teknik analisis varians 2 jalur.

Tabel 1. Desain penelitian ANAVA 2 x 2

\begin{tabular}{cccc}
\hline \multirow{2}{*}{$\begin{array}{c}\text { Teamwork } \\
\text { Skills }(\mathrm{TS})\end{array}$} & $\begin{array}{c}\text { Model Pembelajaran (A) } \\
\text { Tipe } G I \\
(1)\end{array}$ & $\begin{array}{c}\text { Direct } \\
\text { Instruction } \\
(2)\end{array}$ & $\begin{array}{c}\text { Rata- } \\
\text { Rata }\end{array}$ \\
\hline $\begin{array}{l}\text { Di atas } \\
\text { rata-rata (1) }\end{array}$ & $\mathrm{A}_{1} \mathrm{~B}_{1}$ & $\mathrm{~A}_{1} \mathrm{~B}_{2}$ & $\mu_{\mathrm{B} 1}$ \\
\hline $\begin{array}{l}\text { Di bawah } \\
\text { rata-rata (2) }\end{array}$ & $\mathrm{A}_{2} \mathrm{~B}_{1}$ & $\mathrm{~A}_{2} \mathrm{~B}_{2}$ & $\mu_{\mathrm{B} 2}$ \\
\hline Rata-Rata & $\mu_{\mathrm{A} 1}$ & $\mu_{\mathrm{A} 2}$ & \\
\hline
\end{tabular}

\section{HASIL PENELITIAN DAN PEMBAHASAN}

Data Rata-rata hasil belajar berdasarkan desain penelitian ANAVA dua jalur:

Tabel 2. Rata-rata hasil belajar berdasarkan desain penelitian ANAVA dua jalur

\begin{tabular}{lccc}
\hline \multicolumn{1}{c}{$\begin{array}{c}\text { Teamwork } \\
\text { Skills (TS) }\end{array}$} & \multicolumn{2}{c}{ Model Pembelajaran (A) } & Rata- \\
\cline { 2 - 3 } & $\begin{array}{c}\text { Koopetarif } \\
\text { tipe GI }\end{array}$ & $\begin{array}{c}\text { Direct } \\
\text { Instruction }\end{array}$ & Rata \\
\hline $\begin{array}{l}\text { Di atas } \\
\text { rata-rata (1) }\end{array}$ & 74,14 & 41,71 & 61,53 \\
\hline $\begin{array}{l}\text { Di bawah } \\
\text { rata-rata (2) }\end{array}$ & 61,70 & 38,83 & 47,00 \\
\hline Rata-Rata & 70,29 & 40,09 & \\
\hline
\end{tabular}

Hasil uji Hipotesis ANAVA disajikan pada Tabel berikut:
Tabel 3. Hasil uji ANAVA kedua kelas

\begin{tabular}{|c|c|c|c|c|c|}
\hline Source & $\begin{array}{l}\text { Type III } \\
\text { Sum of } \\
\text { Squares }\end{array}$ & Df & $\begin{array}{l}\text { Mean } \\
\text { Square }\end{array}$ & $\mathrm{F}$ & Sig. \\
\hline $\begin{array}{l}\text { Corrected } \\
\text { Model }\end{array}$ & 15679.06(a) & 3 & 5226.35 & 71.82 & .000 \\
\hline Intercept & 171862.63 & 1 & 171862.63 & 2361.80 & .000 \\
\hline Model & 11220.31 & 1 & 11220.31 & 154.19 & .000 \\
\hline LevelTS & 861.19 & 1 & 861.19 & 11.84 & .001 \\
\hline $\begin{array}{l}\text { Model * } \\
\text { LevelTS }\end{array}$ & 335.14 & 1 & 335.14 & 4.61 & .036 \\
\hline Error & 4366.05 & 60 & 72.77 & & \\
\hline Total & 214857.00 & 64 & & & \\
\hline $\begin{array}{l}\text { Corrected } \\
\text { Total }\end{array}$ & 20045.11 & 63 & & & \\
\hline
\end{tabular}

Berdasarkan kriteria pengujian keputusan menggunakan SPSS: Probabilitas $<0.05$ (Santoso, 2005). Berarti:

1. Terdapat perbedaan hasil belajar siswa melalui model kooperatif tipe group investigation dengan direct interuction dalam pembelajaran fisika.

2. Terdapat perbedaan hasil belajar siswa antara kelompok siswa yang memiliki teamwork skills diatas rata-rata dengan kelompok siswa yang memiliki teamwork skills dibawah rata-rata.

3. Terdapat interaksi antara model pembelajaran dengan teamwork skills dalam mempengaruhi hasil belajar fisika siswa.

Analisis Post Hoc Test dengan uji tukey. Hasil yang diperoleh disajikan pada tabel berikut ini:

Tabel 4. Hasil Analisis Post Hoc Test dengan Uji Tukey

\begin{tabular}{|c|c|c|c|c|c|c|}
\hline \multirow[b]{2}{*}{ (I) Interaksi } & \multirow[b]{2}{*}{ (J) Interaksi } & \multirow{2}{*}{$\begin{array}{c}\text { Mean } \\
\text { Difference } \\
(\mathrm{I}-\mathrm{J})\end{array}$} & \multirow{2}{*}{ Std. Error } & \multirow[b]{2}{*}{ Sig. } & \multicolumn{2}{|c|}{$95 \%$ Confidence Interval } \\
\hline & & & & & Upper & Lower \\
\hline \multirow{3}{*}{$\begin{array}{l}\text { DI di bawah } \\
\text { rata-rata }\end{array}$} & \multirow{3}{*}{$\begin{array}{l}\text { DI di atas rata-rata } \\
\text { KGI di bawah rata-rata } \\
\text { KGI di atas rata-rata }\end{array}$} & -2.8810 & 3.03979 & .779 & -10.9137 & 5.1518 \\
\hline & & $-22.8667^{*}$ & 3.36443 & .000 & -31.7572 & -13.9761 \\
\hline & & $-35.3030 *$ & 2.71113 & .000 & -42.4673 & -28.1388 \\
\hline \multirow{3}{*}{$\begin{array}{l}\text { DI di atas } \\
\text { rata-rata }\end{array}$} & \multirow{3}{*}{$\begin{array}{l}\text { DI di bawah rata-rata } \\
\text { KGI di bawah rata-rata } \\
\text { KGI di atas rata-rata }\end{array}$} & 2.8810 & 3.03979 & .779 & -5.1518 & 10.9137 \\
\hline & & $-19.9857^{*}$ & 3.53191 & .000 & -29.3189 & -10.6526 \\
\hline & & $-32.4221 *$ & 2.91638 & .000 & -40.1287 & -24.7155 \\
\hline \multirow{3}{*}{$\begin{array}{l}\text { KGI di } \\
\text { bawah rata- } \\
\text { rata }\end{array}$} & DI di bawah rata-rata & $22.8667^{*}$ & 3.36443 & .000 & 13.9761 & 31.7572 \\
\hline & DI di atas rata-rata & $19.9857^{*}$ & 3.53191 & .000 & 10.6526 & 29.3189 \\
\hline & KGI di atas rata-rata & $-12.4364^{*}$ & 3.25336 & .002 & -21.0334 & -3.8393 \\
\hline \multirow{3}{*}{$\begin{array}{l}\text { KGI di atas } \\
\text { rata-rata }\end{array}$} & DI di bawah rata-rata & $35.3030^{*}$ & 2.71113 & .000 & 28.1388 & 42.4673 \\
\hline & DI di atas rata-rata & $32.4221^{*}$ & 2.91638 & .000 & 24.7155 & 40.1287 \\
\hline & KGI di bawah rata-rata & $12.4364 *$ & 3.25336 & .002 & 3.8393 & 21.0334 \\
\hline
\end{tabular}




\section{Pembahasan Penelitian}

Hasil analisis varians nilai signifikan kelas 0.000 lebih kecil daripada nilai $\alpha=0,05$ sehingga dapat disimpulkan bahwa terdapat perbedaan yang signifikan antara hasil belajar fisika siswa yang diajar dengan menggunakan model pembelajaran KGI dengan model pembelajaran DI. Dimana nilai rata-rata hasil belajar KGI lebih tinggi dibandingkan DI. Ketika menjalankan pembelajaran kooperatif group investigation. Siswa berperan aktif untuk melakukan investigasi untuk membuktikan suatu fenomena fisika. Siswa terlebih dahulu dipahamkan tentang materi dari suatu penomena fisika kemudian membuktikan melalui penyelidikan fenomena yang telah dipahaminya sehingga akan mendatangkan keyakinan akan kebenaran suatu teori fisika. Keterlibatan siswa mulai dari merencanakan, mengumpulkan data, mengolah data, dan menarik kesimpulan akan menguatkan ingatannya terhadap teori fisika. Dengan demikian pemahaman itu akan menguat dan mempengaruhi hasil belajar.

Dengan demikian terdapat perbedaan yang signifikan antara model group investigasi dibandingkan model direct intruction terhadap prestasi akademik siswa (Akcay, 2012). Selain itu dalam model pembelajaran kooperatif hasil belajar siswa lebih tinggi dikarenakan adanya pengembangan kemampuan sosial seperti teamwork skill disamping kemampuan sosial seperti menghormati, mematuhi peraturan, penyelesaian tugas, dan toleransi menggunakan model pembelajaran kooperatif lebih baik dari pada model tradisional (Tavakoli, 2014). Selain itu kelompok siswa investigasi memiliki masalah terkecil untuk membangun kemampuan apresiasi siswa yang membuat siswa lebih aktif dalam melakukan proses belajar mengajar (Purwadi, 2013). Selanjutnya model pembelajaran group investigasi lebih efektif dibandingkan pembelajaran konvensional dalam mempelajari sains dan dapat berfungsi untuk memperbaiki masalah instruksional yang terkait dengan pembelajaran sains yang sulit (Kiboss, 2013). Group investigtion tetap menawarkan peserta didik untuk berkesempatan memiliki pembelajaran mereka sendiri serta menunjukkan pengetahuan dan pemahaman mereka. (Mitchell, 2008)

Selanjutnya hasil analisis varians nilai signifikan TS 0.000 lebih kecil daripada nilai $\alpha$ $=0,05$ sehingga dapat disimpulkan bahwa hasil belajar fisika kelompok siswa yang memiliki tingkat TS di atas rata-rata lebih tinggi daripada kelompok siswa yang memiliki tingkat TS di bawah rata-rata. Perbedaaan hasil belajar terjadi akibat peran teamwork skills dalam mewujudkan tujuan bersama. Saat sekelompok orang bekerja sama tiap anggota tim dapat menutupi kelemahan individu lain yang ada dalam kelompok itu. Dalam proses pembelajaran saat seorang siswa tidak mampu menyelesaikan suatu konsep akan dibantu oleh teman sekelompoknya yang sudah memahami. Saat bekerja sama kemampuan sosial siswa akan lebih menonjol dibandingkan bekerja sendiri. Saling peduli akan lebih baik jika dalam suatu model pembelajaran mengharuskan mereka melakukan presentasi hasil. Demi mendapatkan nilai yang baik seluruh anggota kelompok harus menguasai materi dan tugas-tugas yang dikerjakannya dengan alasan mereka harus tampil menjadi yang terbaik saat melakukan presentasi hasil. Penjelasan ini menjadi jawaban dari hasil penelitian dimana siswa yang memiliki tingkat TS di bawah rata-rata memiliki nilai hasil belajar yang lebih rendah dibandingkan siswa yang memiliki tingkat TS di atas rata-rata. Hasil penelitian juga sesuai dengan teori dimana outpun dari model pembelajaran kooperatif adalah menjadikan siswa meningkatkan prestasi akademik, menerima keragaman, meningkatkan kinerja dalam tugas-tugas akademik, dan mengembangkan keterampilan sosial khususnya kerja sama (Arends, 2007). Teori lain mengungkapkan model pemebelajaran kooperatif memuat prestasi siswa tinggi (Slavin, 1995). Dengan demikian kerja sama yang baik akan meningkatkan hasil belajar yang baik.

Kemampuan bekerjasama dalam tim (teamwork skills) yang diperlukan dalam model pembelajaran kooperatif akan memberikan pelajaran yang bermakna bagi siswa. Semakin 
baik siswa bekerja sama semakin baik pula proses belajarnya dan tentunya memberikan hasil yang baik. Sebuah kelompok belajar yang baik kerja sama teamnya berarti bagus managemennya. Managemen yang baik akan menjadikan proses berjalan dengan baik sehingga akan meningkatkan hasil belajar siswa.

Dengan demikian kemampuan sosial yang baik termasuk bekerja sama dalam kelompok (teamwork skills) akan menjadikan siswa memiliki hasil belajar yang lebih baik dibandingkan siswa yang kemampuan sosialnya kurang baik (Tavakoli, 2014). Kerja sama yang baik berhasil meningkatkan hasil belajar. Kerja sama mengefisienkan penggunaan waktu. Kerja sama menghilangkan masalah penjadwalan dan kontribusi (Garcia, 2013). Siswa yang bekerja sama akan menjaga prioritas masing-masing ke arah tujuan dan bekerja untuk kepentingan tim. Siswa belajar keterampilan seperti komunikasi, partisipasi, negosiasi, kerja sama tim dan presentasi (Kadavakollu, 2013). Dengan demikian siswa yang memiliki tingkat TS di atas rata-rata memiliki hasil belajar yang lebih tinggi dibandingkan siswa yang memiliki tingkat TS di bawah rata-rata.

Selanjutnya hasil analisis varians diperoleh nilai signifikan Model * LevelTS 0,036 lebih kecil dari pada nilai $\alpha=0,05$ maka dapat dikatakan terdapat interaksi antara model pembelajaran dengan TS siswa dalam mempengaruhi hasil belajar.

Berdasarkan hasil uji lanjut dengan analisis Post Hoc Test menggunakan uji tukey dari empat kelompok siswa (DI dengan TS di bawah rata-rata, DI dengan TS di atas rata-rata, KGI dengan TS di bawah rata-rata, KGI dengan TS di atas rata-rata) terdapat enam pasangan yang dapat dibandingkan. Dari enam pasangan tersebut terdapat lima pasangan yang menunjukkan ada perbedaan hasil belajar dan satu pasangan lain menunjukkan tidak terdapat perbedaan hasil belajar. Pasangan yang tidak menunjukkan adanya perbedaan nilai hasil belajar adalah pasangan DI yang memiliki TS di bawah rata-rata dipasangkan dengan DI yang memiliki TS di atas rata-rata.
Hal ini dapat dijelaskan dengan teori bahwa dalam mempengaruhi hasil belajar, team work skills mendukung pada penerapan fase model pembelajaran KGI dibandingkan pada model pembelajaran DI. Model pembelajaran DI adalah model pembelajaran dengan penjelasan langsung dari guru (Joice, 2009). Dengan demikian siswa tidak dilibatkan dalam bekerja sama secara penuh kecuali guru menginstruksikan siswa untuk menyelesaikan suatu tugas secara berkelompok. Hal ini menjelaskan tidak terdapat pengaruh TS secara signifikan pada model DI untuk siswa dengan tingkat TS di bawah rata-rata dan di atas rata-rata. Tidak adanya perbedaan ini terjadi akibat karakteristik model DI itu sendiri. Model DI merupakan model yang berpusat pada guru. Guru berperan aktif melakukan instruksi untuk mengajarkan siswa yang mengakibatkan siswa tidak membutuhkan kemampuan sosial seperti bekerja sama dalam kelompok. Berdasarkan penjelasan ini peran teamwork skills tidak dibutuhkan dalam model pembelajaran DI kecuali sedikit ketika guru menginstruksikan siswa untuk menyelesaikan suatu tugas secara berkelompok. Sehingga teamwork skills dalam model pembelajaran DI tidak akan berpengaruh secara signifikan. Dengan demikian teamwork skills pada model DI tidak mempengaruhi hasil belajar. Dalam penelitian ini pada kelas DI ada kelompok siswa yang memiliki TS di bawah rata-rata dan ada kelompok siswa yang memiliki TS di atas rata-rata dan hasil belajarnya sama dengan sig. 0.779 lebih bedas dari 0.05 yang berarti tidak terdapat perbedaan. Walhasil pada penerapan model DI tidak perlu diperhatikan teamwork skills siswa.

Selanjutnya perbedaan antara KGI di bawah rata-rata dibandingkan dengan KGI di atas rata-rata dengan taraf signifikansi 0.002 . Artinya nilai hasil belajar siswa pada KGI yang memiliki TS di bawah rata-rata berbeda dengan siswa pada kelas KGI yang memiliki TS di atas rata-rata. Hal ini menjelaskan terdapat pengaruh TS secara signifikan pada KGI di atas rata-rata dengan KGI di bawah rata-rata. Hal ini terjadi akibat kebutuhan model KGI itu sendiri yang 
mengharuskan siswa mampu menyelesaikan tugas secara berkelompok. Semakin baik team work skillsnya semakin baik pula proses pembelajaran berlangsung sehingga memberikan hasil belajar yang lebih baik. Dengan demikian tingkat TS mempengaruhi hasil belajar pada model KGI. Model pembelajaran group investigasi lebih efektif dibandingkan pembelajaran konvensional dalam mempelajari sains dan dapat berfungsi untuk memperbaiki masalah instruksional yang terkait dengan pembelajaran sains yang sulit (Kiboss, 2013). Keefektifan itu terjadi karena model KGI menjadikan siswa terlibat secara langsung dalam memahami fenomena fisika. Keterlibatan siswa akan meningkatkan pemahaman siswa terhadap konsep fisika yang mereka pelajari. Keterlibatan siswa dalam sebuah percobaan dan didukung oleh teamwork skills yang tinggi akan menghasilkan hasil belajar yang baik. Siswa akan mampu menuliskan semua yang telah dipahaminya dalam proses belajar mengajar. Tingkat kemampuan menulis siswa yang belajar dengan model investigasi kelompok lebih baik daripada siswa yang belajar dengan model konvensional (Piyoto, 2014).

Secara teori perbedaan tingkat teamwork skills akan mempengaruhi hasil belajar dimana semakin baik kemampuan kerja sama tim seseorang akan mempengaruhi hasil perolehan dari tujuan kelompok (Hughes, 2011). Kemampuan kerja sama berhasil dalam meningkatkan pemahaman siswa. Dengan demikian pemahaman siswa dipengaruhi oleh seberapa besar kemampuan kerja sama siswa (Garcia, 2013). Keterampilan individu dalam tim seperti komunikasi, partisipasi, kerjasama akan mempengaruhi hasil belajar (Kadavakollu, 2013). Walhasil pada penerapan model KGI perlu memperhatikan tingkat teamwork skills siswa.

\section{KESIMPULAN}

Berdasarkan pengolahan data dan pembahasan hasil penelitian yang dilakukan, dapat ditarik kesimpulan:
1. Terdapat perbedaan hasil belajar siswa melalui model kooperatif tipe group investigation dengan direct interuction dalam pembelajaran fisika. Nilai rata-rata hasil belajar fisika pada model kooperatif tipe group investigation lebih tinggi dibandingkan model direct interuction. Dengan perbandingan 70,25 dan 40,09.

2. Terdapat perbedaan hasil belajar siswa antara kelompok siswa yang memiliki teamwork skills diatas rata-rata dengan kelompok siswa yang memiliki teamwork skills dibawah rata-rata. Hasil belajar fisika pada kelompok siswa yang memiliki tingkat teamwork skills di atas rata-rata lebih tinggi dibandingkan kelompok siswa yang memiliki tingkat teamwork skills di bawah rata-rata. Dengan perbandingan 61,53 dan 47,00 .

3. Terdapat interaksi antara model pembelajaran dengan teamwork skills dalam mempengaruhi hasil belajar fisika siswa. Model pembelajaran kooperatif tipe group investigation dapat diterapkan pada kelompok siswa yang memiliki teamwork skills di atas rata-rata maupun kelompok siswa yang memiliki teamwork skills di bawah rata-rata. Sedangkan pada model direct interuction tidak perlu memerhatikan teamwork skills.

\section{DAFTAR PUSTAKA}

Akcay, N. O., Doymus, K. 2012. The Effects of Group Investigation and Cooperative Learning Techniques Applied in Teaching Force and Motion Subjects on Students' Academic Achievements. Jurnal. Educational Sciences research, Vol 2, No 1.

Arends, R. 2007. Learning to teach. Penerjemah: Soetjipto, H.P dan Soetjipto, S.M. Belajar untuk Mengajar. Yogyakarta: Pustaka Pelajar.

Dalyono, M. 2005. Psikologi Pendididkan. Jakarta: Rineka Cipta.

Garcia, A.C. 2013. Helping Undergraduate Students Learn from Each Other: A 
Pedagogical Process for in-Class Collaborative Research Projects. Jurnal. Journal of Education and Practice. Vol.4, No.2, 2013.

Gonzales, P., Leslie, J., Stephen, R., David, K., \& Summer, B. 2011. Highlight from TIMSS 2011: Mathematics and science achievement of u.s. fourthand eighthgrade students in an international context. Institute of Education Science.

Hughes, R. L., Jones, S. K. 2011. Developing and Assessing College Student Teamwork Skills. Wiley Periodicals, Inc.Published online in Wiley Online Library (wileyonlinelibrary.com)

Joyce, B., Weil, M., Calhoun, E. 2009. Model's of Teaching (Model-Model Pengajaran), Yogyakarta: Pustaka Pelajar.

Kadavakollu, T. 2013. Team Work as a Path to Employability-A Case Study. Jurnal. Journal of Education and Practice. Vol.4, No.5, 2013.

Kiboss, J. K., Tanui, E. K. 2013. Effectiveness of e-Learning Investigation Model on Students' Understanding of Classification of Organisms in School Biology. Journal of Education and Practice. Vol.4, No.7.

Mitchell, M, G., Monthgomery H., Holder M. 2008. Group Investigation as a Cooperative Learning Strategy: An Integrated Analysis of the Literature. Jurnal. The Alberta Journal of Educational Research Vol. 54, No. 4.
Pitoyo, A., Waluyo, H., Suwandi, S. 2014. The Effect of Group Investigation Learning Model, Accelerated Learning Team and Role Playing on Elementary School Students' Writing Skills Viewed from Cognitive Style. Journal of Education and Practice. Vol.5, No.1, 2014.

Purwadi, Suwandi, S., Slamet. 2013. The Effect of the Contextual, the Problem-Based, and the Group Investigation Learning Models on the Short Story Appreciation Ability Viewed from the Verbal Linguistic Intelligences. Jurnal. Education and Practice, Vol 4, No. 12

Santoso, S. 2005. Masalah Statistik dengan SPSS. Jakarta: PT Elex Media Komputindo

Slavin, R.E. 1995. Co-operative Learning: Theory, Research, and Practice. (2nd edition), Boston: Allyn and Bacon.

Smith, C. 2011. Teamwork Skills Toolkit. Grifith University. http://www.griffith. edu.au/gihe/teaching-learningcurriculum/graduate-attributes (diakses 30 Januari 2014)

Tavakoli, Y., Soltani, A. 2014. The effect of cooperative learning on students' social skills in the experimental science course. Journal of Education and Practice. ISSN 2222-1735 (Paper) ISSN 2222-288X (Online).Vol.5, No.7 